\section{Bureau of Human Heredity}

THE object of the Bureau of Human Heredity, which has recently been founded (see NaturE, 137, $795 ; 1937)$, is collection on as wide a scale as possible of material dealing with human genetics. Later, the tasks of analysis of material and distribution of the information available will be added. It is affiliated to the International Human Heredity Committee, which ensures co-operation in all areas where research is proceeding. The Council would be grateful to receive all available material from institutions and individuals, furnishing well-authenticated data on the transmission of human traits whatever these may be. Pedigrees are particularly desired; twin studies and statistical researches are also relevant. Announcements in regard to the services undertaken by the Bureau will be published from time to time. The address of the Bureau is 115 Gower Street, London, W.C.1.

\section{Announcements}

DR. H. R. MuL has been elected a member of the German Academy of Naturalists at Halle "in recognition of his original contributions to geographical science and particularly to Oceanography and the furtherance of Polar research". This Academy, the full title of which is the Kaiserlich LeopoldinischCarolinisch Deutsche Akademie der Naturforscher, was founded at Schweinfurth in $\mathbf{1 6 5 2}$ by a group of medical men who called themselves the Argonauts, as their object was to explore new realms of science in order to bring back the 'gold of knowledge' for the benefit of mankind, an aim which it now defines as the study of Nature for the good of humanity.

MR. R. A. WATson WATT has been appointed superintendent of the Air Ministry Research Station, Bawdsey Manor, Suffolk. Mr. Watson Watt began his Civil Service career in the Meteorologieal Office, and later was appointed superintendent of the Radio Research Stations of the Department of Scientific and Industrial Research at Aldershot and Slough. Ho becine superintendent of the Radio Department of the National Physical Laboratory when it was formed in 1933. In this post he has been responsible for an increasing amount of important work for the Air Ministry, especially in connexion with radio direction finders and beacons. His present appointment arises from a decision by that Department to establish a research station to continue this work.

Prof. Franz Fischer, of the Kaiser-Wilhelm Institute, Mulheim-Ruhr, will deliver the Melchett Lecture of the Institute of Fuel at the Institution of Mechanical Engineers, Storey's Gate, St. James's Park, London, S.W.1, on October 15, at 3.30 p.m. The subject of Prof. Fischer's lecture will be "Pro. duction of Synthetic Motor Spirit".

The Prussian Academy of Sciences has awarded the gold Leibniz medal to Prof. Heinrich Lotz, of Berlin, and the silver Leibniz medal to Dr. Ludwig Kohl-Larsen, of Allensbach a. Bodensee.
Prof. Rernhold Riecke, director of the ChemicoTechnical Experimental Institute of the German Porcelain Factory of Berlin and scientific director of the German Ceramic Society, has been nominated an honorary member of the American Ceramic Society.

IN connexion with the research item in NATURE of July 11, p. 83, on the Netherland's Meteorological Institute's publication, "Oceanographic and Meteorological Observations in the China Seas", Mr. H. Keyser, of De Bilt, writes that for the English text very valuable assistance was given by $\mathbf{M r}$. E. W. Barlow, of the Marine Division of the Meteorological Office in London, who took much trouble in correcting the manuscript, etc. Mr. Barlow has also given assistance, "on behalf of international co-operation", in the preparation of Part 2 of the work.

Applications are invited for the following appoint ments, on or before the dates mentioned:

An inspector of agriculture in the Department of Agriculture and Forests, Sudan Government-The Controller, Sudan Government London Office, Wellington House, Buckingham Gate, London, S.W.I (September 15).

Two junior investigators for the Royal Commission on Historical Monuments-The Secretary, 29 Abing don Street, London, S.W.1 (September 19).

An assistant horticultural instructor for the Hampshire County Council-The Clerk, The Castle, Winchester (September 21).

An assistant lecturer in electrical engineering in University College, London-The Secretary (September 23).

An instructor in engineering workshop practice and production engineering in the Borough Polytechnic, London, S.E.1-The Principal (September 23).

A head of the Production, Engineering and Trades Course Section of the Department of Mechanical Engineering, and a lecturer in metallurgy, in the Central Technical College, Birmingham-The Chief Education Oficer (September 26).

An assistant conservator of forests in the Depart. ment of Agriculture and Forests, Sudan Government-The Controller, Sudan Government London Office, Wellington House, Buckingham Gate, London, S.W.1 (September 30).

A biologist for research in the eastern Canadian lobster fishery-The Director, Atlantic Biological Station, St. Andrews, N.B., Canada.

A temporary assistant engineer in the Experi. mental Section of the Ministry of Transport-The Establishment Officer, Ministry of Transport, White. hall Gardens, London, S.W.1.

Architectural and structural engineering assistants in the Design Branch of the Directorate of Fortifica. tions and Works at the War Office-The UnderSecretary of State (C. 5), The War Office, London, S.W.I (quote 8314).

An assistant master to teach zoology in the Swansea Technical College-The Director of Educa. tion, Education Offices, Guildhall, Swansea. 